\title{
HARRY POTTER: A MODERN MAGE HERO
}

Érika de Pádua*

ABSTRACT :

J. K. Rowling's Harry Potter series follows the tradition of fantasy works such as Tolkien's The Lord of the Rings. An important difference from these, however, is that it shows the contemporary mage looking for answers for fundamental existential questions of identity.

KEY WORDS: Harry Potter, Joseph Campbell, mage archetype, fantasy literature, self-knowledge quest.

The commercial success of J. K. Rowling's Harry Potter series has brought the popularity of fantasy literature to evidence. In spite of the worldwide acceptance of this genre, however, fantasy literature has received little attention from the academy. The objective of this thesis is to help fill this gap through the analysis of this series, contributing to the better understanding of its popular appeal. This work follows Joseph Campbell's Myth Criticism, using his rationale that the popularity of fantasy literature relies on its archetypal subtext and mythological roots, which echo the life experience of the reader. Among the many archetypes found in fantasy narratives, this thesis analyses in detail the Mage Archetype, often present in such genre and the core of the Harry Potter series.

In this work, fantasy fiction is defined as a narrative of a novel length, usually with a small group of main characters and plots that describe their journey in an imaginary land, with its own fantastic beings, landscape, culture, language, events and history. More than any other fictional genre, these narratives depend on the suspension of belief, and end with evil conquered and good restored,

* Mestre em Letras: Literatura e outros Sistemas Semióticos (Área de concentração: Literaturas de Expressão Inglesa), 2004. 


\title{
EMTESE
}

Belo Horizonte, v. 9, p. I-28I, dez. 2005

that is to say, order is the re-established. For the purposes of this thesis, I consider as fantasy narratives works such as the Harry Potter series (by Rowling), The Lord of the Rings (by Tolkien), and A Wizard of Earthsea (by Le Guin), among others.

\begin{abstract}
Mage characters are easily identifiable because their quest of knowledge reflects our own, a piece of evidence that represents another possible reason for the fascination that fantasy literature produces on the readers. In order to analyze the complex variations of the mage archetype, I divided it into three main manifestations: the Apprentice Mage, the Wise 01d Mage, and the Dark Mage. They are studied within what I defined as the "Mage's Cycle," a variation of Campbell's Cycle of the Hero, and that is focused on fantasy narratives that involve mage characters. The study of the evolution of each type, especially in the Harry Potter series, shows that the traditional quest of the mage is also present in modern fantasy narratives, added with particular contemporary traits. Moreover, it shows how the manifestation of the Mage Archetype is becoming closer to the modern reader, which may account for the popularity of the fantasy genre.
\end{abstract}

The hero of the Mage Cycle is the Apprentice Mage. In this particular Hero's Cycle, the Apprentice Mage's departure is often towards a magical or parallel world, instead of an ordinary one; the guide is often a representation of the Wise 01d Mage archetype; the confrontation is with the Dark Mage, and made in terms of magical power and wits, and the prize is often personal power and increased experience.

The Mage Cycle is essentially an intellectual quest. The mage's strength does not lie in his physical abilities, and his journey is marked by reasoning, considerations, and questionings. Rationality takes place of emotion, and power comes through studying and learning. Even when the mage receives a material prize, the biggest conquest still is the awareness that he was capable of getting the prize.

The Mage Cycle in Harry's journey is an arc that goes from the first book of the series and is supposed to end in the seventh book, a collection of which five have been published. The Apprentice Mage of the series is Harry Potter, and the 
other main characters that complement his Mage Cycle are Dumbledore as the Wise 01d Mage, and Voldemort as the Dark Mage.

The Harry Potter series presents the Mage Cycle for new audiences, bringing many changes in some of the aspects found in past fantasy narratives. As the result of a mix of fantasy narratives with school novels, for example, the series renews several aspects of the Mage Cycle and the mage archetype, introducing school drama in the old master-student relationship. Another fundamental modification concerns the Apprentice Mage's free will. In the books, Harry can choose whether to accept his quest or not. This freedom of choice is rarely present in fantasy stories, the hero not always being able to decide his fate.

Magic is a crucial concept in fantasy tales because it defines the mage: it is the source of his power, and his raison d'être. Magic in literature is habitually influenced by the way it is manifested in our culture, with some adjustments and different focuses. In the Harry Potter books for example, magic is a neutral power with no inherent qualities. Unlike other fantasy narratives, there are no rituals, no mysticism, and no superstition in the magical world of Hogwarts School of Witchcraft and Wizardry, where most classes reflect this lack of transcendence. Magic in Hogwarts is as rational a subject as technology, and, as such, presents some limitations: it cannot bring dead people back to life, cure all types of diseases, be an endless source of money and happiness, or make people more intelligent.

Along with magic's limitations at Hogwarts, another great change when the series is compared to other fantasy narratives is that the magical world coexists with the technological one. The supernatural world in the series is an alternative version of England instead of an altogether parallel world. It has all the organizations found in the workaday world, with its magical counterparts, such as a Ministry of Magic. All this concurs to the idea that the magical world in contemporary fantasy has become more human and realistic.

The Harry Potter series differs from other classical fantasy narratives in terms of the Apprentice Mage. In Hogwarts Harry is not the sole pupil of the Wise 


\section{EM TESE}

Belo Horizonte, v. 9, p. I-28I, dez. 2005

01d Mage, a common trait in old fantasy literature. His master, Dumbledore, has many other students; in fact, he is the head of the school of magic. Harry also has various teachers, or guides, just like in the mundane world. On top of that, unlike his classmates, Harry does not study simply to learn and master his abilities. He seeks vengeance against the Dark Mage Voldemort, for having killed his parents. The acknowledgment of this mission is a gradual process that goes through the first five books of the series, and each reinforces the main goal of Harry's life: to defeat Voldemort for good. The Apprentice Mage in this case appears with a very curious variation; he seeks magical power to get his revenge.

The call to adventure, an aspect of the Mage Cycle, appears in the Harry Potter series in numerous ways, each time from a different herald: an ow1, letters, Hagrid, Dobby, the Death Eaters, the Dementors. The call of the supernatural world is insistent, and must be acknowledged. Thus, in every book Harry answer the summons to go to Hogwarts. These calls are somewhat similar to the ones in other fantasy narratives. However, the difference is significant because it lies on the way Harry responds to them. He has more freedom than the traditional hero of the Mage Cycle does: he can choose whether he takes the call or not.

As Harry escapes his mundane reality into the magical world, he must cross some frontiers. The thresholds help define Harry as the hero mage, because they are tests of courage and trust. There are two great groups of thresholds in the Harry Potter series; a border between the mundane world and the magical world (which Harry reaches in different ways, sometimes by the magical train for students, or using a flying car), and borders within the magical world from safe to dangerous areas. As in other fantasy narratives, Harry crosses the thresholds and finds himself in an alien magical world, but unlike most of these narratives, he is not an outcast there. On the contrary, he is a legitimate member of the mage society. Differently from other fantasy narratives, the hero mage feels comfortable in the new world, with his new friends and environment.

Harry's first contact with the grandeur of the Hogwarts supernatural world is the peculiar landscape he sees from the window of the Hogwarts Express in the first book, a reminder of how different both worlds are. Hogwarts has a certain 
wild, apparently disorganized, out of control quality, leaving the neat, tamed, and ordered fields of the Muggle world behind. Its dark and hidden places are as vast and labyrinthine as the ones described in other fantasy narratives. It is a contemporary representation of the underworld of Joseph Campbell's Cycle of the Hero.

Other modern variation of the mage archetype narratives is racial issues. The Dark Mage Voldemort incites racial prejudice in the series. As the antithesis of both Harry Potter and Albus Dumbledore, Voldemort is an evil magic force, but his evilness is clearly based on a human weakness: intolerance. Racial concerns in fantasy narratives are something new, and intolerance is an issue present throughout the series.

Morality in the supernatural world of Hogwarts is often more explicit than in the mundane world. This is visible as students are selected to the houses of Gryffindor, Hufflepuff, Ravenclaw, and Slytherin, each representing some specific psychological qualities. The students of Slytherin are resourceful (an approving quality), and at the same time present some disregard for the rules (which make them more prone to evil), and in Gryffindor, the students are courageous. Hogwarts also greatly relies on magical devices to identify moral aspects of the characters, as exemplified with the Sorting Hat, which helps the reader easily recognize the villain and the hero.

In fantasy narratives, the guide repeatedly takes the shape of the Wise 01d Mage. Dumbledore is the Headmaster of Harry's school. Physically, he is like most famous mages in literature, and specifically the hermit in the Tarot. However, the Wise 01d Mage represented by Dumbledore is a modern version of the traditional character: he does not hide his weaknesses and flaws, which can be seen in the way he manipulates Harry to defeat Voldemort. At the same time, Dumbledore also cares about and loves his apprentice, showing traits that are more humane.

Other Hogwarts guides are important because they also help define Harry's path. In the series, they are represented by Professor Quirrell (who teaches about corruption and control), Gilderoy Lockhart (about hypocrisy, vanity, and emptiness), Severus Snape (about the complexity of the mage society), Hagrid (about human feelings), and Sirius Black (about friendship and trust). The variation on the 


\section{EM TESE}

Belo Horizonte, v. 9, p. I-28I, dez. 2005

traditional portrait of the guides in the Mage Cycle lies in the fact that Harry's tutors are more accessible, flawed, and less godlike, which leads to a greater identification with the reader's personal experiences. The apprentice Harry questions his guides, especially his master Albus Dumbledore, who does not always have ready answers. This new variation in the way guides are presented humanizes Harry's journey, in a manner more in tune with the modern psychology of children.

Harry faces various tests, like all heroes of Campbell's Cycle of the Hero. As a traditional hero mage, Harry breaks all the rules his guides impose on him. But his tests are often more closely related to his personal quest; they are tests of identity, not to an external cause. The obstacles are plentiful in the books: Harry's orphan condition, his encounters with Draco Malfoy (his twisted version), the Sorting Hat, all kinds of riddles, encounters with dangerous creatures such as the Dementors, the Triwizard Tournament, are all examples of the challenges he meets. Each triumph boosts Harry's selfconfidence and self-knowledge.

The final battle of the Apprentice Mage takes place as he faces the most dangerous enemy of a11, the Dark Mage. It is marked by the Dark Mage's display of vanity and power of destruction. This is when the Apprentice Mage Harry shows what he has learned during his time at Hogwarts. Harry often defeats Voldemort with the direct or indirect help of Dumbledore or other guides or companions, like Ron and Hermione. Their interference is necessary once the Apprentice Mage is still on his way to master his abilities. After the final confrontation in each book, Harry receives a prize and returns to secular London.

Whereas the prize in other fantasy books can be a unique object and happiness, in the Harry Potter series the prize is mainly knowledge about himself and his history. The contemporary Apprentice Mage is more concerned with his identity and less with material riches, a modern twist in the old manifestations of the archetype. In old mage narratives, the identity quest is hidden in the metaphors of magical powers or in the defeat of enemies, but in the Harry Potter books, the personal issues are exposed. This may indicate that self-knowledge is the main goal of the contemporary mage quests. 
Harry's modernity lies in the fact that he will attain his revenge against Voldemort only if he has knowledge of his own identity. Following the contemporary sensibility, Harry is undertaking an existential quest; he wants to know who he is and what part he plays in the magical world. This aspect is also found in other contemporary mage characters: Ged, in Earthsea; Candy, in Abarat; Gentle, in Imagica; and the children in Narnia, are all in an existential journey.

Hence, the main idea that the analysis of the Harry Potter series reveals is the search for identity that afflicts the modern mage hero. This is a key concept and the main difference between contemporary fantasy and past fantasy novels. It may indicate that the present-day mage is looking for answers for fundamental questions: Who am I? Where do I come from? Where am I going? The new mage is aware that the real power of magic is to know oneself.

RESUMO :

A série Harry Potter de J. K. Rowling segue a tradição das narrativas de fantasia como 0 Senhor dos Anéis, de Tolkien. Diverge das últimas, entretanto, ao revelar o mago contemporâneo em busca de respostas para as questões fundamentais de identidade.

PALAVRAS-CHAVE: Harry Potter, Joseph Campbell, arquétipo do mago, literatura de fantasia, jornada de auto-conhecimento.

REFERENCES :

Barker, Clive. Abarat. Trans. Ricardo Gouveia. São Paulo: Companhia das Letras, 2003. - Imajica. New York: HarperPrism, 1995.

Campbe11, Joseph. The Hero with a Thousand Faces. New York: Princeton UP, 1971.

Le Guin, Ursula K. The Farthest Shore. Earthsea Novels. 3. New York: Bantam, 1984. - The Tombs of Atuan. Earthsea Novels. 2. New York: Bantam, 1984. - A Wizard of Earthsea. Earthsea Novels. 1. New York: Bantam, 1984. 


\section{EMTESE}

Belo Horizonte, v. 9, p. I-28I, dez. 2005

Lewis, C. S. A Cadeira de Prata. Série Narnia. 6. Trans. Paulo Mendes Campos. São Paulo: Martins Fontes, 1997.

- O Cavalo e Seu Menino. Série Narnia. 3. Trans. Paulo Mendes Campos. São Paulo: Martins Fontes, 1997.

- o Leão, A Feiticeira e o Guarda-Roupa. Série

Narnia. 2. Trans. Paulo Mendes Campos. São Paulo: Martins

Fontes, 1997.

- Príncipe Caspian. Série Narnia. 4. Trans. Paulo

Mendes Campos. São Paulo: Martins Fontes, 1997.

- O Sobrinho do Mago. Série Narnia. 1. Trans. Paulo Mendes Campos. São Paulo: Martins Fontes, 1997.

. A Viagem do Peregrino da Alvorada. Série Narnia. 5. Trans. Paulo Mendes Campos. São Paulo: Martins Fontes, 1997.

- A Última Batalha. Série Narnia. 7. Trans. Paulo Mendes Campos. São Paulo: Martins Fontes, 1997.

Rowling, J. K. Harry Potter and the Chamber of Secrets. Harry Potter series. 2. New York: Scholastic, 1999.

- Harry Potter and the Goblet of Fire. Harry Potter series. 4. London: Bloomsbury, 2000.

. Harry Potter and the Order of the Phoenix.

Harry Potter series. 5. London: Bloomsbury, 2003.

. Harry Potter and the Prisoner of Azkaban. Harry

Potter series. 3. London: Bloomsbury, 2000.

- Harry Potter and the Sorcerer's Stone. Harry

Potter series. 1. New York: Scholastic, 1998.

Tolkien, J. R. R. The Lord of the Rings. London: HarperCollins, 1994. 